\title{
UJI CEMARAN MIKROBA PADA INFUS SESUDAH PAKAI DENGAN METODE ANGKA LEMPENG TOTAL (ALT) DAN ANGKA KAPANG KHAMIR (AKK) DI RUMAH SAKIT “Y” DI PONOROGO “.
}

\author{
Charlis Palupi ${ }^{1}$, Alfiyah Nurhayati ${ }^{2}$, \\ ${ }^{1,2)}$ Akafarma Sunan Giri Ponorogo, Jl. Batoro Katong 32 Ponorogo \\ e-mail: ${ }^{1)}$ palupicharlis@gmail.com
}

\begin{abstract}
Abstrak
Latar belakangInfus sesudah pakai adalahsisa infus yang telah dipakai oleh pasien dengan cara memasukkan suatu cairan atau obat ke dalam tubuh melalui rute intravena dengan laju konstan selama periode waktu tertentu. Selain itu pengelolaan infus sesudah pakai yang kurang tepat dapat menyebabkan pertumbuhan mikroorganisme yang berbahaya bagi kesehatan pasien dan pegawai lainnya. Tujuan: Untuk mengetahui adanya cemaran mikroba dan jumlah cemaran mikroba pada infus sesudah pakai di rumah sakit "Y" di Ponorogo. Metode: Sampel infus bekas pakai yang diambil di rumah sakit "Y" di Ponorogo secara purposive sampling. Pengujian mikroba menggunakan Angka Lempeng Total (ALT) dan Angka Kapang Khamir (AKK) sedangkan Analisis data pada penelitian ini menggunakan teknik Standart Deviasi.Hasil Berdasarkan hasil penelitian, Nilai Angka Lempeng Total pada infus sesudah pakai adalah 2,25 x $10^{2} \mathrm{koloni} / \mathrm{ml}$ atau $225 \mathrm{koloni} / \mathrm{ml}$ dan Nilai Angka Kapang Khamir 1,5 x 10 ${ }^{1} \mathrm{koloni} / \mathrm{ml}$ atau $15 \mathrm{koloni} / \mathrm{ml}$. Simpulan dan saran : Infus sesudah pakai yang digunakan pada penelitian ini mengalami pencemaran mikroba dan jamur dan diharapkan harus lebih diperhatikan cara penanganan limbah medis lebih lanjut agar tidak membahayakan petugas, penderita, pengunjung maupun bagi masyarakat di sekitar rumah sakit.
\end{abstract}

Kata Kunci : Infus Sesudah Pakai, ALT, AKK

\begin{abstract}
Used Infusion is infusion that has been used by the patient by inserting a liquid that contain of drug into the body by an intravenous route at a constant rate over a period of time. In addition, the management of used infusion that is less precise can causing the growth of microorganisms that are harmful to the health of patients and other employees. Objective: To determine the presence of microbial contamination and the amount of microbial contamination in infusion after use in the " $Y$ " hospital in Ponorogo. Method: Used infusion samples taken at the " $Y$ " hospital in Ponorogo by purposive sampling. Microbial testing uses the Total Plate Number (ALT) and the Fungal Fungus Number (AKK) while the data analysis in this study uses the Standard Deviation technique. Results Based on the results of the study, the Total Plate Value for infusion after use is $2.25 \times 102$ colonies $/ \mathrm{ml}$ or 225 colony $/ \mathrm{ml}$ and Value of Mushroom Fungus $1.5 \times 101$ colony / ml or 15 colonies / ml. Conclusions and suggestions: After-use infusions used in this study experienced microbial and fungal contamination and it is hoped that more attention must be paid to ways of handling further medical waste so as not to endanger officers, sufferers, visitors or the community around the hospital.
\end{abstract}

Keywords: Infusion after use, ALT, AKK

\section{PENDAHULUAN}

Rumah sakit adalah sarana kesehatan yang menyelenggarakan upaya pelayanan kesehatan yang meliputi pelayanan rawat jalan, rawat inap, pelayanan gawat darurat, pelayanan medik, dan non medik yang dalam melakukan proses kegiatan tersebut akan menimbulkan dampak positif sebagai pelayanan masyarakat dan dampak negatif sebagai penyumbang limbah. Untuk mengatasi dampak tersebut perlu 
diadakannya upaya penyehatan lingkungan rumah sakit yang bertujuan untuk melindungi masyarakat dan petugas rumah sakit akan bahaya pencemaran lingkungan yang bersumber dari limbah rumahsakit (Darmadi, 2008).

Upaya penyelenggaraan kesehatan lingkungan rumah sakit harus sesuai dengan persyaratan kesehatan. Karena rumah sakit juga memiliki berbagai kuman penyakit yang berkembang di lingkungan rumah sakit melalui lantai, udara, air, makanan, alat medis maupun non medis, dan limbah serta sampah rumah sakit.

Infus adalah salah satu bentuk sediaan steril yang masuk dalam tubuh manusia melalui intravena. Pada umumnya cairan infus intravena digunakan sebagai penambah elektrolit, nutrisi, dan pengganti cairan tubuh, mempertahankan fungsi normal tubuh pasien rawat inap yang membutuhkan asupan kalori selama masa penyembuhan. Terapi intravena juga digunakan untuk memberikan cairan ketika pasien tidak dapat menelan, tidak sadar, dehidrasi atau shock, untuk memberikan garam yang diperlukan untuk mempertahankan keseimbangan elektrolit, atau glukosa yang diperlukan untuk metabolisme dan memberikan medikasi (Perry \& Potter, 2006).

Infus sesudah pakai merupakan salah satu limbah yang dihasilkan di rumah sakit, yang mana pengelolaan dan pembuangannya belum tentu aman, sehingga bisa menyebabkan pertumbuhan mikroorganisme yang berbahaya bagi kesehatan pasien dan pegawai lainnya. Pertumbuhan mokroorganisme tersebut bisa menyebabkan penyakit, salah satunya yaitu infeksi nosokomial.

Infeksi nosokomial adalah adanya infeksi yang tampak pada pasien ketika berada di rumah sakit atau ketika berada di fasilitas kesehatan lainnya, dimana infeksi tersebut tidak tampak pada saat pasien diterima di rumah sakit. Infeksi nosokomial terjadi karena banyak faktor, salah satunya faktor lingkungan meliputi udara yang tercemar, air dan makanan yang mengandung pertumbuhan mikroba, kemudian ada faktor medis meliputi alat medis serta limbah rumah sakit. Salah satu penyebab utama infeksi nosokomial adalah limbah, pengelolaan limbah yang kurang baik akan menyebabkan pertumbuhan mikroorganisme yang memicu pertumbuhan penyakit. (Darmadi,2008)

Berdasarkan hal-hal di atas, perlu dilakukan penelitian untuk mengetahui jumlah cemaran mikroba dalam infus habis pakai pada salah satu Rumah sakit swasta di Ponorogo. Analisi dilakukan antara lain: 1) Untuk mengetahui jumlah bakteri yang mencemari infus dextrosa sesudah pakai di Rumah Sakit "Y" dengan metode ALT 2)Untuk mengetahui jumlah jamur yang mencemari infus dextrosa sesudah pakai di Rumah Sakit "Y" dengan metode AKK

\section{METODE PENELITIAN}

Penelitian ini dilaksanakan dengan cara pengujian jumlah bakteri dan jumlah jamur di laboratorium mikrobiologi Akademi Analis Farmasi dan Makanan Sunan Giri Ponorogo. Populasi pada penelitian ini adalah infus sesudah pakai yang ada di rumah sakit " $\mathrm{Y}$ “ di ponorogo di ruang dewasa atau umum. 
Sedangkan sampel yang digunakan adalah infus sesudah pakai dextrosa yang ada di rumah sakit “ $\mathrm{Y}$ “ kemasan $500 \mathrm{ml}$ sebanyak lima botol di ruang dewasa atau umum. Untuk pengambilan sampel, peneliti menggunakan metode purposive, dimana sejumlah sampel sengaja diambil pada ruang dewasa atau umum dari rumah sakit " $\mathrm{Y}$ " yang ada di Ponorogo.

Tehnik pengumpulan datapada penelitian ini adalah dengan pengamatan secara langsung pada sampel .Prosedur analisa pada sampel dimulai dari homogenisasi sampel dengan mempersiapkan alat dan bahan yang telah disterilkan kemudian dimasukkan ke dalam inkas. Memipet $10 \mathrm{ml}$ sampel dan $90 \mathrm{ml}$ pepton cair dimasukkan ke dalam Erlenmeyer $250 \mathrm{ml}$. $\left(10^{-1}\right)$ Uji Angka Lempeng Total : Mempersiapkan tabung reaksi, diletakkan berurutan pada rak tabung dan diberi label seri pengenceran dari $10^{-2}$ sampai $10^{-4}$ masing-masing tabung yang telah diberi label diisi dengan $9 \mathrm{ml}$ pepton,menambahkan $1 \mathrm{ml}$ dari homogenisasi sampel $\left(10^{-2}\right)$,mengambil $1 \mathrm{ml}$ dari tabung $10^{-2}$ memasukkan ke tabung $10^{-3}$ mengambil $1 \mathrm{ml}$ dari tabung $10^{-3}$ ) memasukkan ke tabung $10^{-4}$, memipet $1 \mathrm{ml}$ dari seri pengenceran kemudian dimasukkan ke dalam cawan petri steril, masing-masing dilakukan duplo, menuangkan media nutrient agar pada cawan petri yang terisi sampel, kemudian dicampur dan diratakan,dibiarkan memadat, kemudian bungkus dengan kertas dalam keadaan terbalik, inkubasi pada suhu $37^{\circ} \mathrm{C}$ Selama $24-48 \mathrm{jam}$.

Uji Angka Kapang dan khamirMempersiapkan alat dan bahan yang telah disterilkan kemudian dimasukkan ke dalam inkas,mempersiapkan tabung reaksi, diletakkan berurutan pada rak tabung dan diberi label seri pengenceran $10^{-1}$ sampai $10^{-4}$, masing-masing tabung yang telah diberi label diisi dengan $9 \mathrm{ml}$ pepton, menambahkan $1 \mathrm{ml}$ sampel dari homogenisasi sampel,dari pengenceran tabung $10^{-1}$ dipipet $1 \mathrm{ml}$ dimasukkan ke dalam cawan petri steril menuangkan media SGA pada cawan petri steril yang telah terisi sampel dan dibuat duplo,dibiarkan memadat, kemudian bungkus dengan kertas, inkubasikan pada suhu $20-25^{\circ} \mathrm{C}$ dan amati pada hari ketiga sampai kelima, menghitung koloni yang tumbuh. (Fardiaz,1992)

Teknik analisa data dari hasil penelitian adalah sebagai berikut:Untuk mengetahui Angka Lempeng Total (ALT) pada infus dextrosa bekas pakai yaitu dipilih cawan petri dari salah satu pengenceran yang menunjukkan koloni antara 30-300. Jumlah koloni rata-rata dari kedua cawan dihitung lalu dikalikan faktor pengencerannya. Hasil dinyatakan sebagai Angka Lempeng Total_(ALT) dalam tiap ml sampel.Untuk mengetahui Angka Kapang Khamir (AKK) yaitu dipilih cawan petri dari satu pengenceran yang menunjukkan koloni antara 40-60 koloni. Jumlah koloni rata-rata dari kedua cawan dihitung kemudian dikalikan dengan faktor pengencerannya.Untuk analisis data pada penelitian ini menggunakan analisa statistik dengan Standart Deviasi, adapun rumus perhitungannya adalah sebagai berikut $\mathrm{SD}=\sqrt{\frac{\Sigma(x-x) 2}{n-1}}$ dimana SD merupakan deviasi standart, $\Sigma(\mathrm{x}-\mathrm{x})^{2}$ merupakan jumlah semua deviasi setelah mengalami pengkuadratan, dan $\mathrm{N}$ merupakan number of cases (Rohman, 2007).

\section{HASIL PENELITIAN}


Hasil praktikum Angka Lempeng Total (ALT) dan Angka Kapang Khamir (AKK) dengan sampel dextrosa infus sesudah pakai di rumah sakit "Y" di Ponorogo dengan jumlah lima sampel (A, B, C, D, E) dengan metode Angka Lempeng Total (ALT) dengan pengenceran $10^{-1}$ sampai $10^{-4}$ dengan pengulangan dua kali (duplo) dan metode Angka Kapang Khamir (AKK) dengan pengenceran $10^{-1}$ sampai $10^{-4}$ dengan pengulangan dua kali (duplo).

Tabel 1. Hasil Rata-rata Standart Deviasi Angka Lempeng Total

\begin{tabular}{|c|c|c|c|}
\hline Sampel & Range $(x \pm S D)$ & $X$ & $\begin{array}{l}\text { Kesimpulan rata- } \\
\text { rata }\end{array}$ \\
\hline A & \multirow{5}{*}{$19,03-34,31$} & 485 & - \\
\hline $\mathrm{B}$ & & 185 & - \\
\hline $\mathrm{C}$ & & 35 & - \\
\hline $\mathrm{D}$ & & 25 & $\sqrt{ }$ \\
\hline$E$ & & 20 & $\sqrt{ }$ \\
\hline
\end{tabular}

Tabel 2. Hasil Rata-Rata Standart Deviasi Angka Kapang Khamir

\begin{tabular}{|c|c|c|c|}
\hline Sampel & Range $(x \pm S D)$ & $\mathrm{X}$ & $\begin{array}{l}\text { Kesimpulan rata- } \\
\text { rata }\end{array}$ \\
\hline A & \multirow{5}{*}{$9,23-20,77$} & 10 & $\sqrt{ }$ \\
\hline $\mathrm{B}$ & & 20 & $\sqrt{ }$ \\
\hline $\mathrm{C}$ & & 10 & $\sqrt{ }$ \\
\hline $\mathrm{D}$ & & 20 & $\sqrt{ }$ \\
\hline $\mathrm{E}$ & & 100 & - \\
\hline
\end{tabular}

Keterangan:

$\sqrt{ }$ : diterima

- : ditolak

\section{PEMBAHASAN}

Pemeriksaan Angka Lempeng Total dan Angka Kapang Khamir pada sampel infus i dextrosa sesudah pakai menunjukkan adanya cemaran mikroba bakteri dan jamur. Sampel diambil dari bangsal yang sama dan hari yang sama. Angka Lempeng Total pada sampel infus dextrosa sesudah pakai berdasarkan hasil dari praktikum yang telah dilakukan dengan jumlah mikroba yang dapat dihitung 30-300 koloni/ml. Pada sampel A diperoleh hasil 48,5 x 10-1

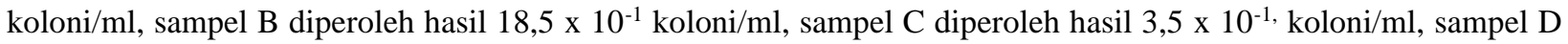
diperoleh hasil 2,5 $\times 10^{-1} \mathrm{koloni} / \mathrm{ml}$, sampel E diperoleh hasil $2 \times 10^{-1} \mathrm{koloni} / \mathrm{ml}$.

Pada saat perhitungan menggunakan Standart Deviasi, hanya ada dua sampel yang diterima, yaitu sampel D dan sampel E, sedangkan sampel A, B, C jumlah koloni melebihi range yang telah ditentukan yaitu 19,03-34,31.

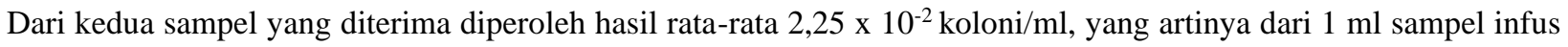
sesudah pakai terdapat cemaran mikroba bakteri sebanyak 225 koloni. Efek negatif yang ditimbulkan pada jumlah Angka Lempeng Total yang tinggi adalah tumbuhnya bakteri mesofil yang bersifat patogen yang dapat menyebabkan keracunan.

Pada pengujian Angka Kapang Khamir diperoleh hasil pengujian yang dilaksanakan untuk menghitung jumlah kapang dan khamir yang ditumbuhkan pada media SGA. Berdasarkan hasil praktikum yang dilakukan pada sampel infus dextrosa sesudah pakai dengan jumlah mikroba yang dapat dihitung 40-60 koloni/ml. Pada sampel A 
diperoleh hasil $1 \times 10^{-1} \mathrm{koloni} / \mathrm{ml}$, sampel B diperoleh hasil $2 \times 10^{-1} \mathrm{koloni} / \mathrm{ml}$, sampel C diperoleh hasil $1 \times 10^{-1}$, koloni/ml, sampel D diperoleh hasil 2 × $10^{-1} \mathrm{koloni} / \mathrm{ml}$, sampel E diperoleh hasil 2 × $10^{-2} \mathrm{koloni} / \mathrm{ml}$.

Pada saat perhitungan menggunakan Standart Deviasi, ada empat sampel yang diterima, yaitu sampel A, B, C, D sedangkan sampel E ditolak karena jumlah koloni melebihi range yang telah ditentukan yaitu 9,23-20,77. Dari kelima sampel yang diterima diperoleh hasil rata-rata $1,5 \times 10^{-1}$ koloni/ml, yang artinya dari $1 \mathrm{ml}$ sampel infus sesudah pakai terdapat cemaran mikroba jamur sebanyak 15 koloni. Jumlah Angka Kapang Khamir yang tinggi dapat menyebabkan tumbuhnya jamur yang menghasilkan aflatoksin.

Dari penelitian ini diketahui bahwa sampel infus dextrosa sesudah pakai di salah satu rumah sakit di Ponorogo memiliki jumlah bakteri dengan menggunakan metode Angka Lempeng Total dan Angka Kapang Khamir. Dari hasil Angka Lempeng Total dan Angka Kapang Khamir yang diperoleh, maka harus lebih diperhatikan cara penanganan limbah medis yang lebih lanjut agar tidak membahayakan petugas, penderita, pengunjung maupun bagi masyarakat di sekitar rumah sakit.

Efek negatif yang ditimbulkan dari adanya cemaran mikroba bakteri pada jumlah Angka Lempeng Total yang tinggi adalah tumbuhnya bakteri mesofil yang bersifat pathogen yang dapat menyebabkan keracunan. Bakteri mesofil yaitu bakteri yang hidup pada daerah suhu antara $15-55^{\circ} \mathrm{C}$, dengan suhu optimum $25-40^{\circ} \mathrm{C}$, Contoh: Escherichia coli penyebab diare

Salmonella typhosa penyebab penyakit tifus,Vibrio comma penyebab penyakit kolera,Shigella dysenteriae penyebab penyakit disentri,Haemophilus influenza penyebab penyakit influenza.

Angka Kapang Khamir yang tinggi dapat menyebabkan tumbuhnya jamur yang menghasilkan aflatoksin, jamur tersebut sebagai berikut:Rhizopus stolonifer (warna hitam), jamur ini biasanya tumbuh pada jenis roti, bisa menyebabkan keracunan.Rhizopus oligosporus (warna putih kekuningan), jamur ini biasanya tumbuh pada nasi, bisa menimbulkan gangguan pencernaan atau infeksi usus.Penicillium notatum (warna hijau), jamur ini biasanya tumbuh pada kentang, kacang, dan makanan yang sudah busuk, bisa menyebabkan epitel mulut putih pada anak-anak (Irianto,2006)

\section{SIMPULAN}

Dari hasil penelitian dapat ditarik simpulan, Infus sesudah pakai yang digunakan pada penelitian ini mengalami pencemaran mikroba bakteri dan jamur dengan jumlah Angka Lempeng Total pada infus dextrosa sesudah pakai adalah $2,25 \times 10^{2} \mathrm{koloni} / \mathrm{ml}$ atau $225 \mathrm{koloni} / \mathrm{ml}$, sedangkan Angka Kapang Khamir pada infus sesudah pakai adalah $1,5 \times 10^{1} \mathrm{koloni} / \mathrm{ml}$ atau $15 \mathrm{koloni} / \mathrm{ml}$

\section{REFERENSI}

Darmadi, 2008. Infeksi Nosokomial: Problematika Dan Pengendaliannya. Jakarta: Salemba Medika 
Fardiaz, Srikandi.1992. Analisis Mikrobiologi Pangan Edisi 1. Jakarta: Gramedia Umum..

Irianto, Koes.2002.Mikrobiologi:Menguak Dunia Mikroorganisme Jilid I. Bandung: Yrama Widya.

Potter, P.A, Perry. A.G. 2006. Buku Ajar Fundamental Keperawatan: Konsep, Proses dan Praktik. Edisi 4 (volume 3). Jakarta: EGC.

Rohman, Abdul. 2007. Kimia Farmasi Analisis. Yogyakarta: Pustaka Pelajar 